Molekul, Vol. 4. No. 2. November, 2009 : 73 - 82

\title{
SIFAT-SIFAT BIOKIMIAWI EKSTRAK KASAR LIPASE EKSTRASELULER DARI BAKTERI Azospirillum sp. JG3
}

\author{
Puji Lestari $^{1}$, Santi Nur Handayani ${ }^{1}$ dan Oedjijono ${ }^{2}$ \\ ${ }^{1}$ Program Studi Kimia, Jurusan MIPA Fakultas Sains dan Teknik UNSOED, Purwokerto \\ ${ }^{2}$ Fakultas Biologi UNSOED, Purwokerto
}

\begin{abstract}
Lipases are valuable biocatalysts because they act under extremely mild conditions, are stable in organic solvents, show broad substrate specificity and exhibit high stereoselectivity. Lipases play important role in various industries such as detergent, cosmetics, flavor, pharmacy and synthesis of organic compounds. The increasing of lipases requirements in industries is goading research to get new lipases resources commited. One of potential lipase resource is Azospirillum sp.JG3 bacteria from Microbiology Laboratory of Biology Faculty University of Jenderal Soedirman. The specific targets of this research are to get crude extract of lipase and investigate its biochemical characteristics. The method used were rejuvenation of Azospirillum sp.JG3 bacteria, inoculum production, determination of optimum production time and bacterium growth phase, extraction and production of lipase to get crude extract, and characterization the biochemical properties of lipase crude extract. The research resulted that crude extract of lipase from Azospirillum sp.JG3 had optimum temperature at $40{ }^{\circ} \mathrm{C}$ and optimum $\mathrm{pH}$ at $\mathrm{pH}$ 7. The lipase was a metalloenzyme with $\mathrm{Ca}^{2+}$ as its cofactor. The lipase was stable in three organic solvents tested, (chloroform, n-hexane and ether).
\end{abstract}

Keywords : Azospirillum sp. JG3, lipase activity, biochemical characteristics

\section{PENDAHULUAN}

Lipase (E.C.3.1.1.3) adalah enzim yang mengkatalisis reaksi hidrolisis ester asamkarboksilat dalam lemak atau minyak dan sintesis monoester. Lipase mengkatalisis reaksi hidrolisis ester asam karboksilat atau reaksi sintesis monoester secara stereoselektif dan enantioselektif (Snellman and Colwell, 2004). Lipase merupakan enzim yang paling banyak digunakan sebagai katalis berbagai reaksi senyawa organik (Reetz, 2002). Lipase adalah biokatalis yang berperan besar dalam aplikasi bioteknologi, seperti dalam sintesis biopolimer, biodiesel, produksi obat, dan produksi flavor (Joseph et al, 2007).

Produksi lipase secara komersial telah dilakukan di beberapa negara maju. Harga lipase impor relatif mahal, misalnya harga lipase dengan merk dagang Lipozyme IM, BIO-lipase, dan Lipolase mencapai 25 juta rupiah per $\mathrm{kg}$ (Kao Corporation, 2004 dalam Putranto dkk., 2006). Indonesia dengan keanekaragaman hayati tinggi berpeluang besar mengembangkan produksi lipase dari mikroba lokal, salah satunya adalah bakteri.

Beberapa genus bakteri yang diketahui mampu menghasilkan enzim lipase adalah Pseudomonas, Alcaligenes, Serratia, dan Micrococcus (Fardiaz, 1993). Bakteri merupakan salah satu mikroba yang dapat menghasilkan enzim lipase, karena memiliki kemampuan hidup di berbagai lingkungan yang terdapat kandungan makanan atau nutrisi yang kompleks. Keuntungan memproduksi enzim dari mikroba adalah 
produksi enzim dapat ditingkatkan dalam skala besar dalam ruangan yang relatif terbatas (Suhartono, 1989).

Jenis bakteri yang digunakan pada penelitian ini adalah bakteri penambat nitrogen Azospirillum sp. JG3. Pengujian kualitatif sifat enzimatis isolat Azospirillum sp. JG3 yang dilakukan oleh Oedjijono dkk. (2007) menunjukkan bahwa isolat tersebut mampu menghasilkan enzim lipase. Hasil penelitian menunjukkan bahwa bakteri Azospirillum sp. JG3 mampu menghasilkan ekstrak kasar lipase dengan aktivitas sebesar 0,3 Unit/100 mL. Aktivitas lipolitik isolat Azospirillum sp. JG3 muncul pada pertengahan masa fermentasi yaitu setelah jam ke-12 pada saat laju pertumbuhan spesifik 0,081 (Oedjijono dkk., 2007). Berdasarkan hasil penelitian dan informasi tentang potensi lipase sebagai biokatalis dalam bidang industri, maka penting dilakukan penelitian untuk mengkarakterisasi beberapa sifat-sifat biokimiawi ekstrak kasar lipase dari Azospirillum sp. JG3.

\section{METODE PENELITIAN}

\section{Bahan dan Alat}

Bahan utama yang digunakan dalam penelitian ini adalah isolat murni Azospirillum sp. JG3 koleksi Laboratorium Mikrobiologi Fakultas Biologi Universitas Jenderal Soedirman, dan minyak kelapa komersial. Bahan lain yang digunakan adalah medium NA (Nutrient Agar) dan NB (Nutrient Broth) instant, $\mathrm{NaCl}$, gum arab, buffer Natrium asetat, buffer Natrium fosfat, buffer Tris$\mathrm{HCl}$, buffer Natrium karbonat, EDTA, $\mathrm{CaCl}_{2}, \mathrm{CuCl}_{2}, \mathrm{MgCl}_{2}, \mathrm{ZnCl}_{2}, \mathrm{CoCl}_{2}$, aseton, etanol, $\mathrm{NaOH}$, indikator fenolftalein, kloroform, n-heksana, eter dan aquades.

Alat-alat yang digunakan dalam penelitian ini adalah alat-alat gelas yang umum dipakai pada laboratorium, kawat ose, $\mathrm{pH}$ meter "Hanna Instrument", perangkat titrasi (mikro buret dan statif), shaker bath, pipet mikro otomatis merk Wheaton Soccorex, sentrifuge "T 120", shaker incubator merk Kotterman, autoklaf, spektrofotometer UV-Vis merk Shimidzu UV-1601.

\section{Prosedur penelitian \\ Peremajaan isolat Azospirillum sp.JG3}

Isolat murni Azospirillum sp. JG3 dari stok murni pada medium gliserol ditumbuhkan pada medium NA (Nutrient Agar) dan diinkubasi selama $2 \times 24$ jam pada suhu ruang. Pemindahan isolat murni Azospirillum sp.JG3 dilakukan menggunakan jarum ose secara aseptis.

\section{Pembuatan inokulum Azospirillum sp.JG3}

Isolat murni Azospirillum sp. JG3 hasil peremajaan di medium NA diinokulasikan ke dalam medium NB (Nutrient Broth), kemudian diinkubasi pada shaker incubator pada suhu ruang selama 30 jam. Setiap 3 jam sekali sampel diambil dan diukur OD (optical density) dengan spektrofometer visibel pada $\lambda 600 \mathrm{~nm}$ untuk menentukan kurva pertumbuhan sel. Inokulum yang diinokulasikan ke dalam medium produksi adalah inokulum yang berada pada fase eksponensial berdasarkan kurva pertumbuhan sel.

\section{Pembuatan kurva produksi lipase}

Kurva produksi lipase dibuat untuk menentukan masa inkubasi yang menghasilkan lipase dengan aktivitas tertinggi. Sebanyak $20 \mathrm{ml}$ inokulum pada fase eksponensial diinokulasikan ke dalam $100 \mathrm{ml}$ medium NB (sebagai medium fermentasi) dalam Labu Erlenmeyer $500 \mathrm{ml}$ yang diperkaya dengan emulsi minyak kelapa $1 \%$ sebagai induser (Prazeres et. al., 2006). Medium produksi yang mengandung inokulum diinkubasi dalam shaker incubator pada suhu ruang selama $2 \times 24$ jam. Pengambilan cuplikan dilakukan setiap 6 jam sekali untuk diukur aktivitas 
lipase dan OD. Sebagian disentrifus dengan sentrifus dingin $\left(6000 \mathrm{rpm}, 4{ }^{\circ} \mathrm{C}\right.$, 10 menit). Supernatan yang didapat merupakan ekstrak kasar lipase dan diukur aktivitasnya. Data yang diperoleh berupa nilai aktivitas lipase dan kepadatan sel.

\section{Pengukuran Aktivitas Lipase}

Aktivitas lipase diukur menggunakan metode titrimetri yang diadaptasi dari Prazeres et al (2006). Substrat yang digunakan adalah emulsi minyak kelapa $25 \%$ dalam larutan gum arab $7 \%$ yang dicampur hingga homogen. Campuran reaksi enzim terdiri dari $5 \mathrm{ml}$ emulsi minyak kelapa, $4 \mathrm{ml}$ buffer fosfat $50 \mathrm{mM} \mathrm{pH} 7$ yang diinkubasi selama 5 menit pada suhu $35{ }^{\circ} \mathrm{C}$, kemudian ditambahkan $1 \mathrm{ml}$ enzim dan inkubasi dilanjutkan selama 30 menit. Reaksi dihentikan dengan penambahan $5 \mathrm{ml}$ aseton:etanol (1:1). Asam lemak yang dibebaskan dititrasi menggunakan $\mathrm{NaOH}$ $50 \mathrm{mM}$ yang telah distandarisasi. Aktivitas lipase ditentukan dari volume $\mathrm{NaOH}$ untuk titasi sampel dikurangi volume $\mathrm{NaOH}$ untuk titrasi kontrol. Setiap $1 \mathrm{ml} \mathrm{NaOH} 50 \mathrm{mM}$ setara dengan 100 unit aktivitas lipase.

Unit aktivitas enzim dihitung dengan

$=\underline{(\mathrm{V} \mathrm{NaOH} \text { sampel }-\mathrm{V} \mathrm{NaOH} \text { kontrol }) \times 100}$ volume enzim

\section{Produksi lipase}

Produksi lipase dilakukan dengan cara yang sama seperti pembuatan kurva produksi dengan waktu inkubasi yang menghasilkan aktivitas lipase tertinggi. Produksi lipase dilakukan dalam Labu Erlenmeyer 1 liter dengan medium fermentasi yang diperkaya emulsi minyak kelapa 1\% sebagai induser. Ekstrak kasar lipase yang didapat diukur volume, aktivitas, dan kadar protein. Kadar protein ditentukan menurut metode Lowry (Bollag et al., 1996). Karakterisasi lipase yang dilakukan meliputi suhu optimum, $\mathrm{pH}$ optimum, pengaruh EDTA dan ion logam terhadap aktivitas lipase, serta pengaruh pelarut organik terhadap aktivitas lipase.

\section{Karakterisasi Lipase}

Penentuan suhu optimum aktivitas lipase (Faiz, et al, 2007)

Penentuan pengaruh suhu terhadap aktivitas lipase ditentukan pada kisaran suhu 25-75 ${ }^{\circ} \mathrm{C}$. Prosedur pengujian aktivitas lipase pada berbagai suhu dilakukan dengan prosedur yang sama dengan pengukuran aktivitas lipase. Suhu yang menghasilkan aktivitas tertinggi ditetapkan sebagai suhu optimum.

\section{Penentuan pH optimum aktivitas lipase} (Faiz et al, 2007)

Pengaruh $\mathrm{pH}$ terhadap aktivitas lipase ditentukan pada kisaran $\mathrm{pH}$ 5-9 dengan berbagai variasi buffer yang sesuai dengan konsentrasi $50 \mathrm{mM}$ pada suhu optimum. Buffer yang digunakan adalah Natrium asetat $(\mathrm{pH}$ 3,6-5,6), Natrium fosfat $(\mathrm{pH} \mathrm{5,7-8),} \mathrm{Tris-} \mathrm{HCl}(\mathrm{pH}$ 7,5-8,2), dan $\mathrm{NaHCO}_{3}$ (pH 9,2-10,7). Prosedur pengujian aktivitas lipase pada berbagai $\mathrm{pH}$ dilakukan dengan prosedur yang sama dengan pengukuran aktivitas lipase. Nilai $\mathrm{pH}$ yang menghasilkan aktivitas tertinggi ditetapkan sebagai $\mathrm{pH}$ optimum.

\section{Pengaruh EDTA dan ion logam terhadap aktivitas lipase (Faiz, et al, 2007)}

Pengaruh ion logam terhadap aktivitas lipase ditentukan dengan menambahkan $1 \mathrm{mM}$ larutan garam $\mathrm{CaCl}_{2}, \mathrm{CuCl}_{2}, \mathrm{MgCl}_{2}, \mathrm{ZnCl}_{2}, \mathrm{CoCl}_{2}$, dan EDTA ke dalam campuran reaksi enzim, kemudian diuji aktivitasnya pada suhu dan $\mathrm{pH}$ optimum. Setiap larutan garam dan EDTA ditambahkan ke dalam lipase dengan perbandingan 1:1. Kontrol adalah campuran reaksi enzim tanpa penambahan larutan garam dan EDTA. 
Pengaruh Pelarut Organik terhadap Aktivitas Lipase (Eltaweel et. al., 2005)

Pengaruh pelarut organik seperti eter, n-heksana, dan kloroform terhadap aktivitas dan kestabilan enzim lipase ditentukan sama seperti pada uji aktivitas enzim. Ekstrak kasar enzim ditambahkan ke dalam pelarut organik dengan perbandingan $3: 1 \quad(\mathrm{v} / \mathrm{v}), \quad$ kemudian diinkubasi selama 30, 60, 90, 120 menit pada suhu optimum dan diuji aktivitasnya.

\section{HASIL DAN PEMBAHASAN Produksi Lipase}

Produksi lipase dari isolat bakteri Azospirillum sp.JG3 diawali dengan peremajaan isolat murni, pembuatan kurva pertumbuhan bakteri Azospirillum sp.JG3, dan pembuatan kurva produksi lipase. Pembuatan kurva pertumbuhan bakteri Azospirillum sp.JG3 dilakukan untuk menentukan umur inokulum pada fase eksponensial karena pada fase eksponensial akan digunakan sebagai inokulum untuk produksi lipase. Kurva pertumbuhan bakteri Azospirillum sp.JG3 tertera pada Gambar 1.

Pertumbuhan mikroba dalam suatu medium mengalami beberapa fase, yakni fase adaptasi (fase lag), fase pertumbuhan awal, fase logaritmik (fase eksponensial), fase pertumbuhan lambat, fase pertumbuhan statis, fase menuju kematian, dan fase kematian (Fardiaz, 1993). Berdasarkan hasil penelitian yang ditampilkan pada Gambar 1 menunjukkan bahwa isolat bakteri Azospirillum sp.JG3 mengalami mengalami fase adaptasi dari jam ke-0 sampai jam ke-9. Saat fase adaptasi berakhir, masing-masing sel mulai membelah dan organisme memasuki fase pertumbuhan awal. Isolat bakteri Azospirillum sp.JG3 mengalami fase pertumbuhan awal pada jam ke-9 sampai jam ke-12 yang ditandai dengan meningkatnya jumlah sel bakteri secara signifikan.

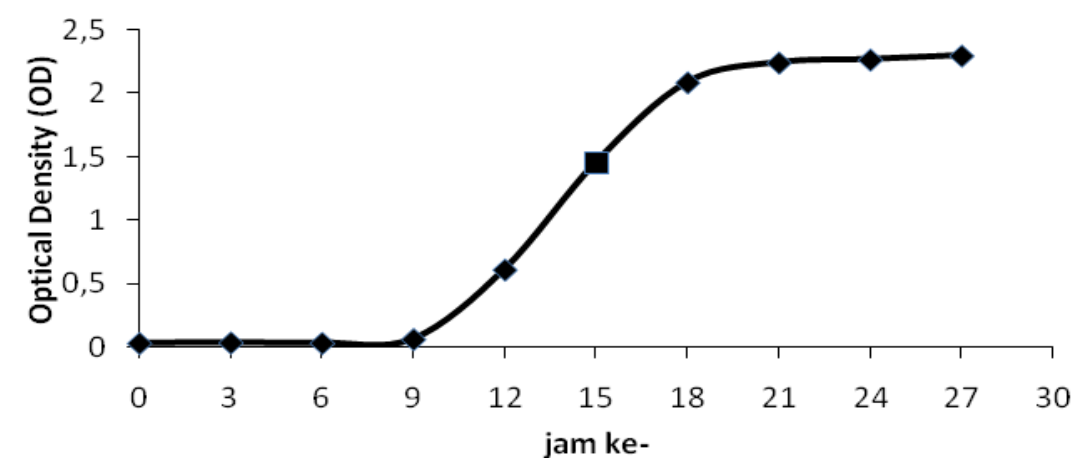

Gambar 1. Kurva pertumbuhan isolat bakteri Azospirillum sp.JG3

Fase logaritmik (eksponensial) terjadi pada jam ke-12 sampai jam ke-18. Fardiaz (1993) menyatakan bahwa pada fase ini sel membelah dengan cepat dan konstan. Berdasarkan hasil penelitian diketahui bahwa isolat bakteri Azospirillum sp.JG3 memiliki laju pertumbuhan paling cepat pada waktu inkubasi 15 jam. Oleh karena itu, inokulum yang digunakan untuk produksi lipase adalah inokulum yang berumur 15 jam. Fase pertumbuhan lambat isolat bakteri Azospirillum sp.JG3 terjadi pada waktu inkubasi 18 jam sampai 27 jam.

Pembuatan kurva produksi lipase bertujuan untuk mengetahui waktu inkubasi yang menghasilkan lipase dengan aktivitas tertinggi. Hasil pengukuran kepadatan sel dan aktivitas enzim lipase yang dihasilkan oleh isolat bakteri Azospirillum sp.JG3 tertera pada Gambar 2. 


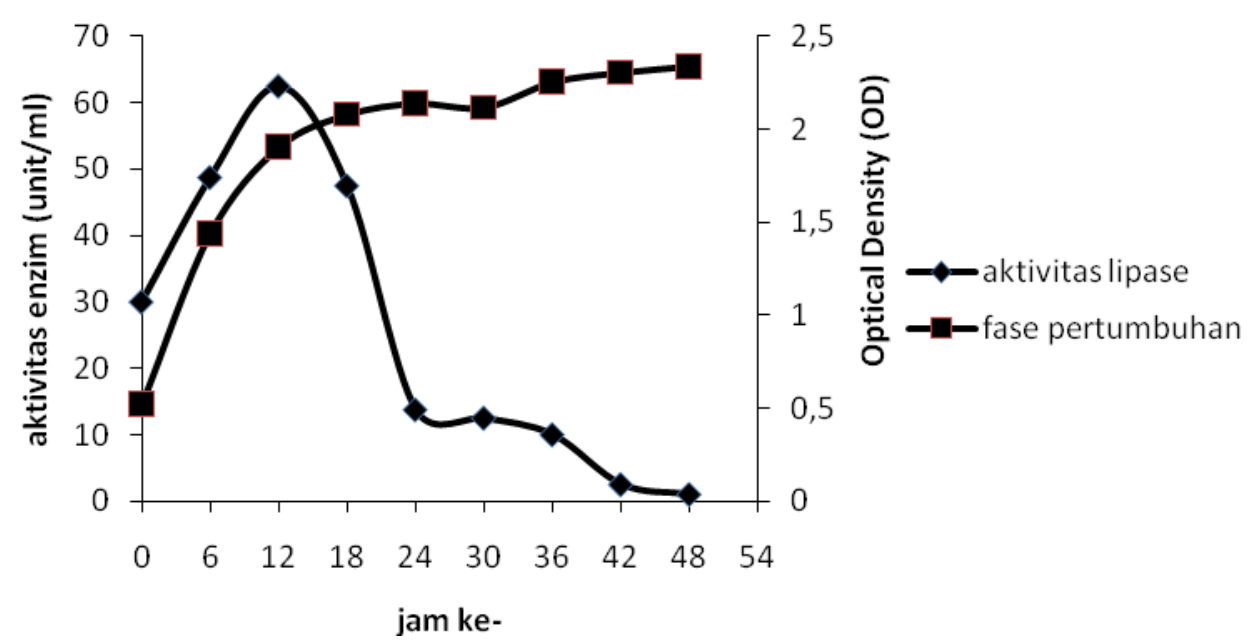

Gambar 2. Kurva produksi lipase dan pertumbuhan bakteri Azospirillum sp.JG3

Berdasarkan hasil penelitian yang ditampilkan pada Gambar 2, Azospirillum sp. JG3 mengalami fase eksponensial pada inkubasi jam ke-0 sampai jam ke18, selanjutnya fase stasioner hingga inkubasi 48 jam. Azospirillum sp. JG3 pada medium produksi tidak mengalami fase lag (fase adaptasi), karena bakteri yang dimasukkan ke dalam medium produksi telah mengalami adaptasi pada medium inokulum sehingga bakteri pada medium produksi telah siap membelah (Volk dan Wheeler, 1988). Aktivitas lipase meningkat pada waktu inkubasi 6 sampai 12 jam. Aktivitas tertinggi lipase tercapai pada fase eksponensial akhir dengan lama inkubasi 12 jam dan aktivitas enzim sebesar 62,50 $\mathrm{U} / \mathrm{ml}$. Aktivitas lipase terus menurun ketika pertumbuhan Azospirillum sp. JG3 mencapai fase stasioner. Bhumibhamon et al. (2002) melaporkan bahwa lipase yang dihasilkan oleh Pseudomonas sp. dengan medium produksi yang diperkaya minyak palm mempunyai aktivitas optimum sebesar $72,10 \mathrm{U} / \mathrm{ml}$ pada fase eksponensial akhir.

Waktu produksi optimum lipase yang diperoleh yaitu masa inkubasi 12 jam digunakan untuk produksi lipase dalam jumlah yang lebih besar. Produksi lipase dilakukan dengan menumbuhkan inokulum pada fase eksponensial yaitu inokulum umur 15 jam ke dalam medium produksi (medium NB) yang diperkaya dengan emulsi minyak kelapa $1 \%$, kemudian diinkubasi selama 12 jam. Medium produksi selanjutnya disentrifugasi $\left(6000 \mathrm{rpm}, \quad 4{ }^{\circ} \mathrm{C}, \quad 10\right.$ menit). Supernatan yang diperoleh merupakan ekstrak kasar lipase. Volume ekstrak kasar lipase yang dihasilkan adalah $968 \mathrm{~mL}$ dengan aktivitas sebesar $25 \mathrm{Unit} / \mathrm{mL}$, kadar protein $4,46 \mathrm{mg} / \mathrm{mL}$, dan aktivitas spesifik 5,61 Unit/mg protein. Karakterisasi sifat-sifat biokimiawi terhadap ekstrak kasar lipase yang dilakukan adalah penentuan suhu dan $\mathrm{pH}$ optimum, pengaruh EDTA dan ion logam terhadap aktivitas lipase serta pengaruh pelarut organik terhadap aktivitas lipase.

\section{Karakterisasi Lipase \\ Penentuan suhu optimum}

Penentuan suhu optimum dilakukan pada $\mathrm{pH}$ 7. Hasil penelitian diperlihatkan pada Gambar 3. 


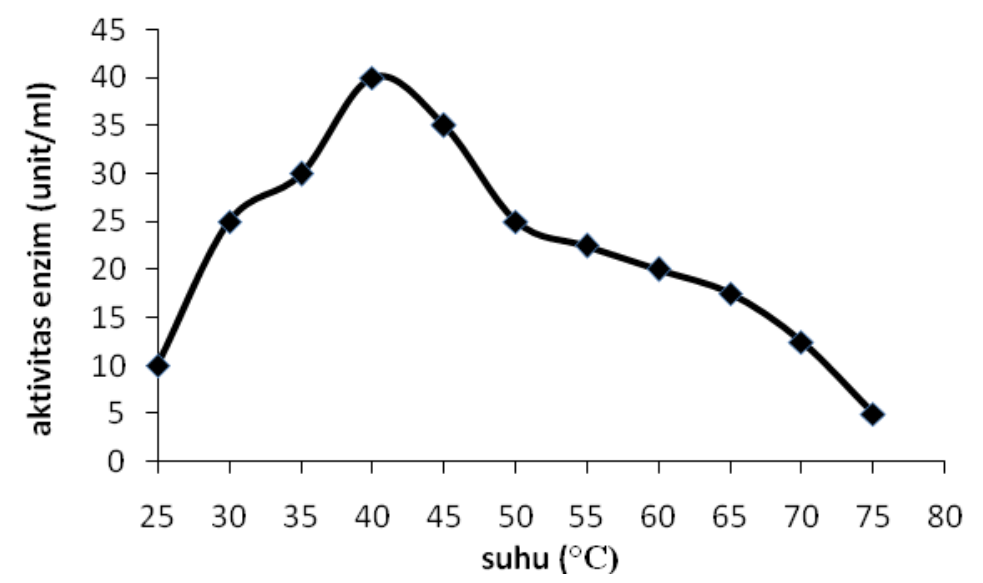

Gambar 3. Grafik penentuan suhu optimum aktivitas lipase

Berdasarkan hasil penelitian, suhu optimum lipase adalah $40{ }^{\circ} \mathrm{C}$ dengan nilai aktivitas sebesar $40 \mathrm{U} / \mathrm{mL}$ Gambar 3). Handayani dan Sulistyo (2005) melaporkan bahwa lipase yang diperoleh dari Bacillus subtilis mempunyai suhu optimum pada suhu $40{ }^{\circ} \mathrm{C}$ dengan aktivitas sebesar $5,98 \mu \mathrm{mol} / \mathrm{menit}$. Menurut Gupta, et. al. (2004) lipase yang diisolasi dari bakteri memiliki suhu optimum pada kisaran $30-60{ }^{\circ} \mathrm{C}$, sedangkan menurut Volk dan Wheeler (1988) kebanyakan enzim mempunyai aktivitas optimum pada suhu antara 30 dan $40{ }^{\circ} \mathrm{C}$.

Aktivitas enzim meningkat seiring dengan meningkatnya suhu dan menurun setelah mencapai suhu optimum. Aktivitas enzim terhadap suhu dipengaruhi oleh energi kinetik enzim dan substrat untuk saling bertumbukan. Meningkatnya suhu menyebabkan energi kinetik meningkat. Pada suhu rendah, sebelum suhu optimum, aktivitas lipase lebih rendah daripada aktivitas lipase di suhu optimum. Hal ini karena tumbukan yang terjadi antara enzim dengan substrat intensitasnya masih rendah sehingga kompleks enzim-substrat yang terbentuk sedikit dan produk yang dihasilkan juga sedikit. Peningkatan suhu sampai suhu optimum meningkatkan tumbukan yang terjadi antara enzim dengan substrat sehingga aktivitas enzim juga meningkat. Pada suhu optimum, tumbukan antara enzim dengan substrat sangat efektif sehingga kompleks enzim-substrat semakin mudah terbentuk dan produk yang dihasilkan juga meningkat. Peningkatan suhu di atas suhu optimum menyebabkan aktivitas enzim menurun. Hal ini karena enzim terdenaturasi sehingga terjadi perubahan struktur tiga dimensi enzim yang menyebabkan substrat sukar berikatan dengan sisi aktif enzim akibatnya aktivitas enzim menurun (Sadikin, 2002).

\section{Penentuan pH optimum}

Penentuan $\mathrm{pH}$ optimum enzim lipase dilakukan pada suhu $40{ }^{\circ} \mathrm{C}$ dengan variasi $\mathrm{pH}$ 5-9. Hasil penelitian ditampilkan pada Gambar 4. 


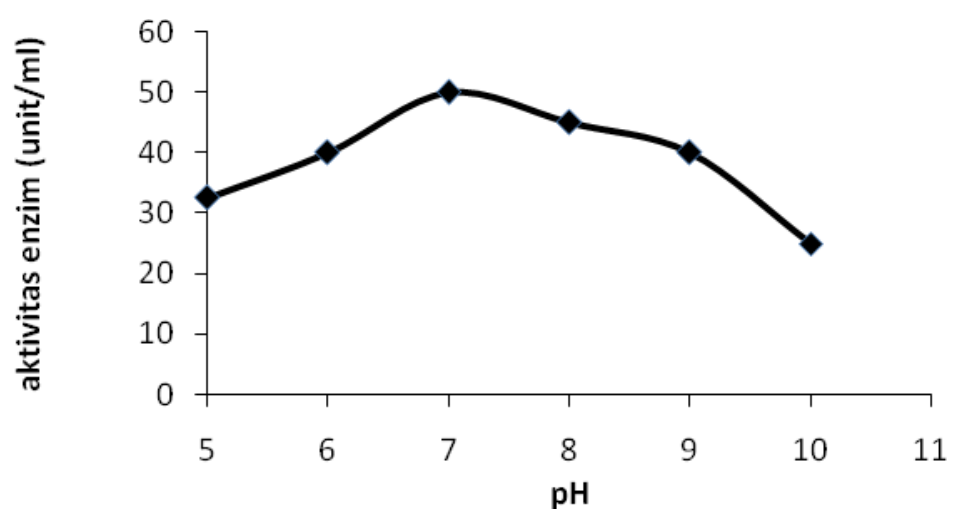

Gambar 4 Grafik penentuan $\mathrm{pH}$ optimum aktivitas lipase

Berdasarkan hasil penelitian, $\mathrm{pH}$ optimum lipase adalah 7 dengan nilai aktivitas sebesar $50 \mathrm{U} / \mathrm{mL}$ (Gambar 4). Handayani dan Sulistyo (2005) melaporkan bahwa lipase yang diproduksi dari Pseudomonas aerogenes dan $B$. substilis mempunyai $\mathrm{pH}$ optimum pada $\mathrm{pH} 7$ dengan aktivitas masingmasing sebesar 5,81 $\mu \mathrm{mol} / \mathrm{menit}$ dan 5,85 $\mu \mathrm{mol} / \mathrm{menit}$. Fozan (2000, dalam Faiz et. al., 2007) menyatakan secara umum aktivitas optimum lipase terjadi pada kisaran pH 6 sampai 8.

Aktivitas lipase pada $\mathrm{pH}$ di bawah dan di atas $\mathrm{pH} 7$ lebih kecil dari pada aktivitas lipase pada $\mathrm{pH}$ 7. Pada kondisi $\mathrm{pH}$ optimum, gugus pemberi dan penerima proton yang penting pada sisi katalitik enzim mempunyai struktur tiga dimensi yang paling sesuai dengan substrat sehingga dapat mengikat substrat dengan tepat, membentuk kompleks enzim-substrat dan menghasilkan produk secara maksimum. Aktivitas lipase di luar $\mathrm{pH}$ optimum rendah karena enzim mengalami denaturasi. Pada $\mathrm{pH}$ rendah, enzim terprotonasi dan kehilangan muatan negatifnya, sedangkan pada $\mathrm{pH}$ tinggi, substrat terionisasi sehingga kehilangan muatan positifnya (Page, 1989).

\section{Pengaruh penambahan EDTA dan ion logam terhadap aktivitas lipase}

Penentuan pengaruh penambahan EDTA dan ion logam terhadap aktivitas lipase dilakukan pada suhu optimum 40 ${ }^{\circ} \mathrm{C}$ dan $\mathrm{pH}$ optimum 7. Ion-ion logam yang digunakan adalah $\mathrm{Ca}^{2+}, \mathrm{Mg}^{2+}$, dan $\mathrm{Co}^{2+}, \mathrm{Cu}^{2+}$, dan $\mathrm{Zn}^{2+}$. Hasil penelitian ditampilkan pada Gambar 5.

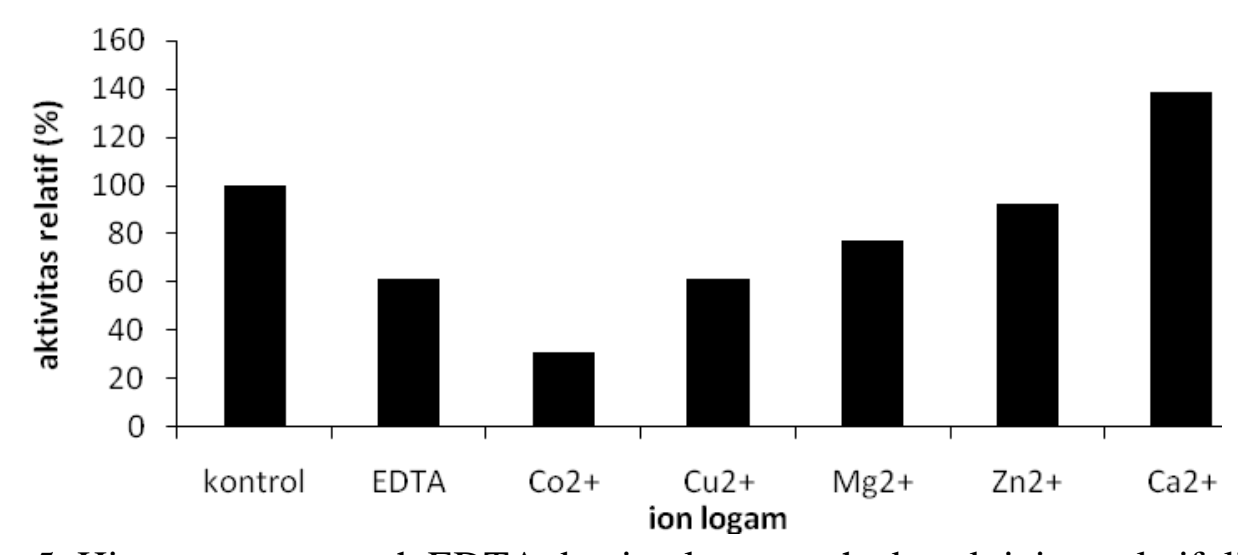

Gambar 5. Histogram pengaruh EDTA dan ion logam terhadap aktivitas relatif lipase 
Uji pengaruh penambahan EDTA dan ion logam menunjukkan bahwa penambahan EDTA menurunkan aktivitas relatif lipase menjadi $61,53 \%$ (Gambar 5). EDTA mengkhelat logam pada sisi aktif lipase sehingga struktur enzim berubah dan enzim kehilangan sisi katalitiknya (Sindumarta dan Natalia, 1999). Hal ini menunjukkan bahwa ekstrak kasar lipase merupakan metaloenzim, yaitu kelompok enzim yang mempunyai ikatan yang erat dengan logam. Penambahan ion $\mathrm{Ca}^{2+}$ meningkatkan aktivitas relatif ekstrak kasar lipase menjadi $138,46 \%$. Hal ini menunjukkan bahwa ion $\mathrm{Ca}^{2+}$ merupakan kofaktor bagi ekstrak kasar lipase. Ion $\mathrm{Co}^{2+}, \mathrm{Cu}^{2+}, \mathrm{Mg}^{2+}$, dan $\mathrm{Zn}^{2+}$ menurunkan aktivitas relatif ekstrak kasar lipase menjadi $30,76 \%, 61,53 \%, 76,92 \%$, dan $92,30 \%$. Oleh karena itu, ion $\mathrm{Co}^{2+}, \mathrm{Cu}^{2+}$, $\mathrm{Mg}^{2+}$, dan $\mathrm{Zn}^{2+}$ merupakan inhibitor bagi ekstrak kasar lipase. Bumibhamon, et. al.
(2002) melaporkan bahwa aktivitas lipase yang diperoleh dari Pseudomonas sp. KLB1 ditingkatkan oleh ion $\mathrm{Ca}^{2+}$ dengan aktivitas relatif sebesar $151,59 \%$ dan dihambat oleh ion $\mathrm{Co}^{2+}$ dan EDTA dengan aktivitas relatif sebesar 75,84\% dan 95,63\%. Kofaktor pada umumnya merupakan molekul anorganik yang berikatan dengan enzim untuk menjaga bentuk sisi aktif enzim agar tetap berada pada konformasi yang tepat, sehingga enzim dapat berikatan dengan substrat membentuk kompleks enzim-substrat dan membentuk produk (Manitto, 1992).

\section{Pengaruh pelarut organik terhadap aktivitas lipase}

Penentuan pengaruh pelarut organik terhadap aktivitas lipase dilakukan pada suhu optimum $40{ }^{\circ} \mathrm{C}$ dan $\mathrm{pH}$ optimum 7. Hasil penelitian ditampilkan pada Gambar 6.

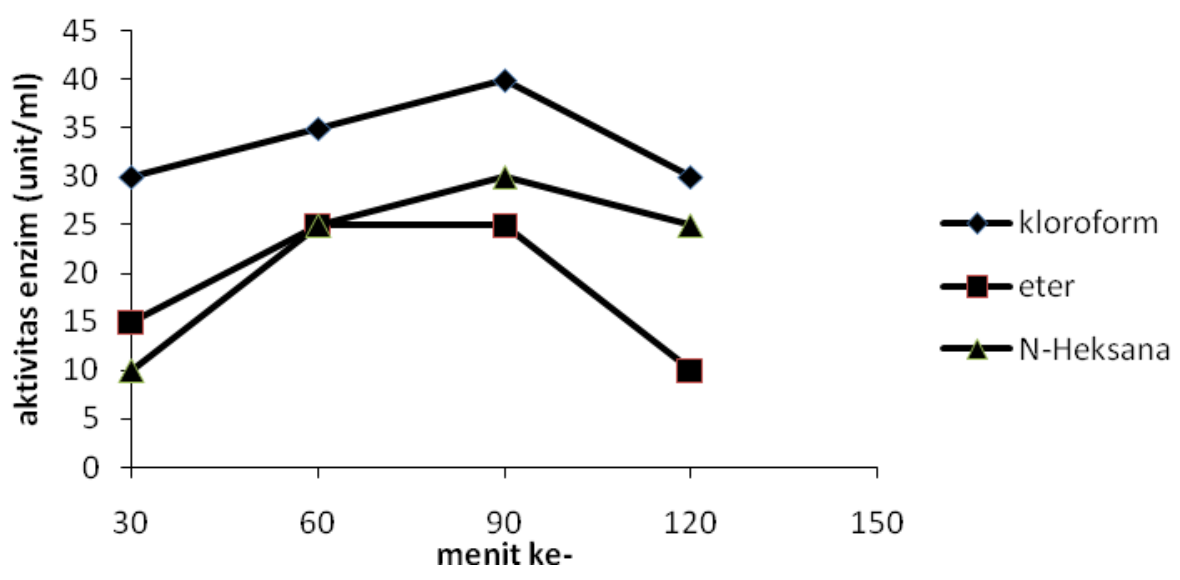

Gambar 6. Grafik penentuan pengaruh pelarut organik terhadap aktivitas lipase

Hasil penelitian menunjukkan bahwa aktivitas lipase paling tinggi dalam pelarut organik kloroform. Aktivitas lipase pada penambahan pelarut organik kloroform tetap stabil hingga 90 menit inkubasi. Penambahan pelarut organik n-heksana menghasilkan aktivitas yang lebih rendah daripada pelarut organik kloroform, namun aktivitasnya stabil hingga 90 menit inkubasi. Aktivitas lipase pada penambahan pelarut organik eter paling rendah namun aktivitasnya stabil hingga 90 menit inkubasi.

Pengaruh pelarut organik yang berbeda-beda terhadap kestabilan lipase disebabkan oleh perbedaan kepolaran masing-masing pelarut organik tersebut. Lipase paling stabil pada penambahan pelarut organik kloroform yang bersifat sedikit polar karena dapat meningkatkan kelarutan substrat sehingga mempercepat reaksi hidrolisis trigliserida menjadi asam 
lemak bebas dan gliserol (Rahman et. al., 2006).

\section{KESIMPULAN DAN SARAN Kesimpulan}

Berdasarkan hasil penelitian yang telah dilakukan, dapat disimpulkan:

1. Ekstrak kasar lipase Azospirillum sp. JG3 mempunyai unit aktivitas enzim sebesar $25 \mathrm{U} / \mathrm{mL}$, kadar protein 4,46 $\mathrm{mg} / \mathrm{ml}$, dan aktivitas spesifik 5,61 Unit/mg protein.

2. Karakteristik biokimiawi ekstrak kasar lipase Azospirillum sp. JG3 adalah mempunyai suhu optimum 40 ${ }^{\circ} \mathrm{C}, \mathrm{pH}$ optimum 7 , merupakan metaloenzim dengan kofaktornya adalah ion $\mathrm{Ca}^{2+}$. Aktivitas lipase relatif stabil dengan penambahan pelarut organik kloroform, eter, dan n-heksana pada suhu dan $\mathrm{pH}$ optimum.

\section{Saran}

Perlu dilakukan penelitian lebih lanjut untuk memurnikan ekstrak kasar lipase, kemudian ditentukan karakteristik biokimiawinya, mengetahui bobot molekul lipase, sekuen asam amino penyusun lipase, dan prediksi struktur tiga dimensi lipase.

\section{UCAPAN TERIMA KASIH}

Ucapan terima kasih disampaikan kepada Lembaga Penelitian Unsoed dan Dirjen Dikti Depdiknas yang telah memberikan dana Hibah Bersaing bagi terlaksananya penelitian ini. Ucapan terima kasih juga disampaikan kepada tiga mahasiswa kimia yang telah membantu terlaksananya penelitian ini yaitu Ratna Citra Andriyana (H1A005040), Setya Muhdiana Muftianingsih (H1A005032) dan Maria Ulfah (H1A005013).

\section{DAFTAR PUSTAKA}

Bollag, D. M., S. J. Edelstein, and M. D. Rozycki. 1996. Protein Methods. John Willey and Sons, Inc. New York.

Bhumibhamon, O., J. Jinda., and S. Fungthong. 2002. Isolation and Characterization of Pseudomonas sp. KLB1 Lipase from High Fat Wastewater (on-line). http://www.thaiscience.info/articl e. Diakses tanggal 5 Oktober 2009.

Eltaweel, M. A., R. N. Z. R. A. Rahman, A. B. Saleh, and M. Basri. 2005. An Organic Solvent-Stable Lipase From Bacillus sp. Strain 42. Annals microbiology. 55: 187192.

Faiz, O., Saghlam, N., Colak, A., Canakci, S., and Belduz, A.O. 2007. Determination and Characterization of Thermostable Esterolytic Activity from a Novel Thermophilic Bacterium Anoxybacillus gonensis A4. Journal of Biochemistry and Molecular Biology 40: 588-594.

Fardiaz, S. 1993. Mikrobiologi Pangan, Jilid 1. Penerbit PT. Gramedia Pustaka Utama, Jakarta.

Gupta, R., N. Gupta, and P. Rathi. 2004. Bacterial Lipases an Overview of Production, Purification and Biochemical Properties. Appl. Microbiology. Biotechnology. 64: 763-781.

Handayani, R dan J. Sulistyo. 2005. Transesterifikasi Ester Asam Lemak melalui Pemanfaatan Teknologi Lipase. Biodiversitas . 6: 164-167. 
Joseph, B. , P.W. Ramteke, G.Thomas, and N. Shrivastava. 2007. Standard Review Cold-active microbial Lipases: a versatile tool for industrial applications. Biotecnology and Molecular Biology Review. Vol.2 (2): 039048.

Manitto, P. 1992. Biosintesis Produk Alam. IKIP Semarang Press, Semarang.

Nurhasanah dan D. Herasari. 2008. Pemurnian Enzim Lipase dari Bakteri Lokal dan Aplikasinya dalam Reaksi Esterifikasi. Prosiding Seminar Nasional Sains dan Teknologi-II 2008, 1718 November 2008, Lampung.

Oedjijono, D. Ryandini, and I.D.S.A.P. Permiarti 2007. Aktivitas Enzimatis Azospirillum pada Substrat Onggok dan Dedak . Laporan penelitian Program Penelitian Dasar (Tidak dipublikasikan). Program Fakultas Biologi Unsoed, Purwokerto.

Page, D. S. 1989. Prinsip-Prinsip Biokimia. Erlangga, Jakarta.

Prazeres, J.N., Cruz, J.A., and Pastore, G.M. 2006. Characterization of Alkaline Lipase from Fusarium oxysporum and the Effect of Different Surfactants and Detergents on the Enzyme Activity. Brazilian Journal of Microbiology 37:505-509.

Putranto, R. A., D. Santoso, T. Panji, Suharyanto, dan A. Budiani. 2006. Karakterisasi Gen Penyandi Lipase dari Kapang Rhizopus oryzae dan Absidia corymbifera. (on-line). http://www.ipard.com. Diakses Tanggal 20 Maret 2009.

Rahman, R. N. Z. A., S. N. Baharum, A. B. Salleh, and M. Basri. 2006. S5 Lipase: an Organic Solvent Tolerant Enzym. The Journal of Microbiology. 44 (6):583-590.

Reetz, M.T., 2002. Lipases as Practical Biocatalyst. Current Opinion in Chemical Biology, 6 : 145-150.

Sadikin, M. 2002. Biokimia Enzim. Widya Medika, Jakarta.

Sindumarta, M. dan D. Natalia. 1999. Biokimia I: Struktur dan Katalis. Penerbit ITB, Bandung.

Snellman, E.A and R.R. Colwell. 2004. Acinetobacter Lipases: Molecular Biology, Biochemical Properties and Biotechnological Potential. Journal of Industrial Microbiology \& Biotechnology. Review Paper.

Suhartono, M. T. 1989. Enzim dan Bioteknologi. PAU Bioteknologi IPB, Bogor.

Volk, W. A dan M. F., Wheelar. 1988. Mikrobiologi Dasar. Erlangga, Jakarta. 